\title{
NEMZETÁLLAMI VÁROSPOLITIKÁK ÉS AZ EURÓPAI UNIÓ POLICENTRIZMUS KONCEPCIÓJA
}

\author{
(Conception of EU Policentrism and State City Policies) \\ SOMLYÓDYNÉ PFEIL EDIT
}

\begin{abstract}
Kulcsszavak:
kohéziós politika városhálózat policentrizmus decentralizált koncentráció területi tervezés

A nemzeti várospolitikákban, a városi térségek és városhálózatok együttmüködésének intézményesülésében paradigma-váltás érzékelhetö az uniós tagországokban. Ennek keretét az EU strukturális politikája szolgáltatja, mivel a területi kohézió erösitésének egyik akadályozó tényezöje a városok elhelyezkedésének területi egyenlötlensége. A cikkben bemutatásra kerülö várospolitikai változások összefüggésben állnak egyfelöl a tagországok közigazgatási szerkezetének modernizációjával és hatékonyságának javitásával, másfelöl a városok gazdasági fejlödése, versenyképessége erösitésének kényszerével. Az elemzés legfontosabb üzenete, hogy a policentrizmus koncepció megvalósitási szintje a regionális szint, mind a nemzetállamon belül, mind nemzetközi értelemben, ami azzal tehetö teljessé, ha a decentralizáció államszervezési elvét ötvözzük a területi koncentráció principiumával. Más ország gyakorlatából számba vehetök olyan tanulságok, melyek iránymutatásként szolgálhatnak a magyar döntéshozók számára városhálózatunk kezeléséhez és fejlesztéséhez, illetve policentrikusabbá tételéhez.
\end{abstract}

\section{Elözetes gondolatok}

Az utóbbi tizenöt évben a közigazgatás müvelöje igencsak bajban van, amikor városokról vagy városi térségekről szeretne beszélni magyarországi viszonylatban. Miközben a társdiszciplínák minden gond nélkül használják a városi vonzáskörzet, a városrégió, az agglomeráció, a városkörnyék vagy éppen a fejlesztési pólus fogalmát, addig a közigazgatás-tudomány szempontjából egyik sem bír relevanciával. Hazánkban a rendszerváltás óta hiányzik az a jogi és szervezeti keret, amelybe a városok és városi térségek beilleszthetők lennének, nem létezik adekvát intézménye a városi vonzáskörzetek együttmüködésének, közös tervezésének és fejlesztésének, nem beszélve működtetésükről.

Természetesen tovább firtatható, hogy vajon a fennálló szabályozási keret a területi politika számára megfelelő vonatkoztatási pontokat szolgáltat-e? Szerencsére az új Országos Területfejlesztési Koncepció 2005. év végi elfogadása óta már nem kell berzenkednie a kutatónak a két szemléleti bázis összekapcsolása végett, hiszen a Koncepció melléklete maga fogalmazza meg, hogy a területi harmóniát és a kiegyensúlyozott területi fejlődést a közigazgatás és a fejlesztéspolitika együttesen szolgálja [95/2005. (XII. 25.) OGY hat. Melléklet II.]. Kiindulópontunk tehát az a területi és közigazgatási jövőkép, mely szerint cél a jelenleginél intenzívebben kooperáló, kiegyensúlyozott városhálózat megteremtése, melyben a pólusok és a nagyvárosok (megyei jogú városok), mint alközpontok hálózatosan együttműködnek. 
Vagyis egy harmonikus, policentrikus együttmüködő városhálózati rendszer képe körvonalazódik a 2013-ig elérendő területi célok között. Az elemző akkor töpreng el igazán azon, mennyi a tisztázásra váró kérdés, amikor az OTK rögzíti a hét NUTS2-es régió fejlesztési céljait, s a VI. fejezetben a fejlesztési pólus mellé fölveszi a „regionális növekedési zóna” fogalmát, amit földrajzilag azonosít. Míg azonban a fejlesztési pólus fogalma szerepel a tervdokumentumhoz csatolt fogalommagyarázatban, addig a regionális növekedési zónát hiába keressük.

Időközben befejeződni látszanak az országos koncepcióban kijelölt fejlesztési pólusok stratégiai tervezési munkái az Új Magyarország Fejlesztési Terv részeként, ami jelzi, hogy a fejlesztési pólus fogalma lassú és hosszú kristályosodási folyamatának végéhez közeledik. A fogalmi nehézségek nem kevéssé abból fakadnak, hogy a hazánkban a kijelölt fejlesztési pólusok és a hozzájuk kapcsolódó fejlesztési tengelyek kialakítása egy egyértelmüen fölülről, államilag kezdeményezett és közforrásokból táplálkozó programot testesít meg, miközben elvi szinten egyértelmüen a területi gazdaság fejlesztése célzódik meg benne. A pólus-városokban a területi klaszterépítés klasszikus modelljét kellene létrehozni a vállalatok, a közszereplők, valamint a kutató és képző intézmények területi koncentrációjának megvalósításával hálózatos együttmüködés révén, a public-private partnerség elve mentén. Egy lényegében „új regionalizációnak” (Küpper-Röllinghoff 2005) nevezhetö folyamatról van szó, mely összhangban van az EU strukturális politikájával, s amely az innováció és növekedés terén mind nagyobb hangsúlyt helyez az urbánus térségekre. Eszerint ma már nemigen létezhet olyan városa, régiója Európának, mely klaszterprojekt nélkül létezhet, illetve olyan kormányzat, mely gazdaságpolitikáját ne klaszterstratégiára alapozná.

A versenyképességi pólusoknak az ÚMFT-be való beépülése nagy fegyvertény, aminek tétje, hogy

- a kijelölt nagyvárosok mindenekelőtt tágabb térségükre gyakoroljanak innovációs és gazdaságfejlesztési hatást;

- a fejlesztési pólussá avanzsált városok nemzetközi városhálózatba bekapcsolódásuk és gazdasági potenciáljuk révén érjék el az ún. nemzetközi láthatóságot.

Tekintettel azonban arra, hogy másfél évtizede nem rendelkezik az ország városfejlesztési politikával, de válaszokkal sem arra, hogy a városhálózatot egészében tudjuk kezelni, számos kérdés maradt nyitott a strukturális alapok 2007 és 2013 közötti tervezési periódusára. Az idekapcsolódó problémák folyamatosan felszínre bukkantak a pólus-programok tervezése során, hiszen legnagyobb városaink egyúttal azokra is szerettek volna megoldást találni (Somlyódyné Pfeil 2006). Ilyen például a városok intraregionális funkcióinak megerösítése, ami több esetben a nemzetközi szintű városi együttműködéseknek a pólus-stratégiákba való benyomulását eredményezte; vagy a városfejlesztési elemeknek az erőteljes megjelenése a régióközpontépítés igényével, mely központok kijelölésére a szakma mintegy tíz év óta vár.

A policentrizmus koncepció Európa területi fejlődésében elválaszthatatlan a kohézió, illetve a területi kohézió gondolatától. Azt is lehet mondani, hogy az EU Amszterdami szerződésébe (EGV) 1999-ben bekerült társadalmi és területi kohézió 
fogalma lényegében járulékos legitimációt biztosított, illetve további fölhatalmazást adott a közös területfejlesztési politika folytatására. Valójában azonban a kiegyensúlyozott és policentrikus városhálózat kialakításának célja, mint az európai területfejlesztési politika alapja, már 1994-es első német elnökség idején megjelent, tekintettel arra, hogy azt a területrendezésért, építésügyért és városépítészetért felelős német Szövetségi Minisztérium dolgozta ki. Mint a későbbiekben bemutatandó nemzeti politikákból ki fog derülni, nem véletlenül. Míg hazánkban a legutóbbi időkig az „Európa a régiók Európája” megközelítés uralkodik, addig az EU szintjén a városok közötti kapcsolatok már éppen olyan fontosak, mint a régió közöttiek. Azonban Európa policentrikus és kiegyensúlyozott fejlődésének víziójában a két szemléletmód összekapcsolódik: nem csupán az Unió központi régióiban koncentrálódó gazdasági növekedés ellensúlyozását célozza, hanem éppen regionális szinten kezdeményezi a városok együttmúködési hálózatainak létrehozását közös területi stratégiák kidolgozására, közös cselekvésre, szemben a domináns városcentrum-modellel.

Nem véletlen tehát, hogy a kohéziós politika és a városok kapcsolata a strukturális alapok hatályos szabályozásának elökészítése során különös hangsúlyt kapott. A 2007-tel elinduló új tervezési időszakban ugyanis a Bizottság elvárása, hogy a Strukturális Alapok beavatkozásainak hozzáadott értéke azáltal is növekedjék, hogy a városi ügyek szisztematikusan integrálódnak a fö operatív programokba, ugyanis a növekedés motorjait jelentő városok sikeres akcióinak kulcselemként kell megjelenniük. Még konkrétabban a tagállamok irányában követelményként fogalmazódott meg, hogy az NSRK-ban a nemzeti és regionális fejlesztési politikával összhangban jelöljenek ki városfejlesztési stratégiát. Ha adott nemzetállamnak a soron következő tervezési időszakra (2007-2013) nincs városfejlesztési stratégiája, akkor valójában magyarázattal tartozik a Bizottságnak, miért nem tartja azt relevánsnak (Halender 2006). Ezt hazánk elmulasztotta és nem határozott meg prioritási tengelyt a városfejlesztés számára, másfelől viszont a pólus-programok támogatható tevékenységeinek az ÚMFT-ben, illetve a különböző operatív programokban történt szétszórt elhelyezésével veszélybe került az is, hogy azok megvalósítása a városfejlesztéssel integráltan történhessen meg.

Az Unió jelenleg rendkívüli módon támogatja az integrált megközelítést, ami a városi térségek esetében az ún. „,URBAN method” alkalmazására vonatkozó ajánlást is jelenti. Ez nem más, minthogy a városi térségek összes problémáját egységes szemléletben igyekszik megközelíteni és tagállamaitól is elvárja. E módszer nagy hangsúlyt helyez a helyi partnerségre, a governance alkalmazására, mellyel mobilizálni kívánja a magán és a közszféra erőforrásait a kohéziós politika és a városi problémák megoldásának összekapcsolása során, s nem kevéssé épít a hálózatok kialakítására (Niessler 2006). Az „URBAN method” is rávilágít arra, hogy a városok a lisszaboni stratégia teljesítésének kiemelt szereplőivé váltak. Fokozott szerepvállalásukat mi sem bizonyítja jobban, minthogy a Tanács 2006 októberében kiadott új stratégiai irányelveiben a kohéziós politika számára kijelölt három követendő prioritás közül az elsőben a városokat a tagállamokkal és régiókkal egy sorban említi, amikor attraktivitásuk fejlesztéséről beszél (2006/702/EC ANNEX 1.). 


\section{Paradigmaváltás a városfejlesztés nemzetközi porondján}

Az EU strukturális és kohéziós politikája egyértelmü hatással bír a tagállamok várospolitikai döntéshozására, hasonlóképpen kedvez a közigazgatás szférájában zajló regionalizálás és decentralizáció a városrégiók és városhálózatok képződésének, az együttmüködések szervezeti formába öntésének. A nyolcvanas évek apátiája után a városi térségek kezelése élénk szakmai viták kereszttüzébe került, s több régi uniós tagállamban a közjogi szabályozásnak ismételten kiemelt területévé váltak a városi vonzáskörzetek, agglomerációk. Ebben az összefüggésben egyfajta paradigmaváltás érzékelhető.

Az alábbiakban néhány kiválasztott régi uniós tagországnak azokat a területi tervezési eszközeit, intézkedéseit, reformlépéseit, valamint az adott ország területi fejlődési jövőképét ismertetjük vázlatosan, melyek összefüggésbe hozhatók az Unió szintjén elfogadott Európai Területfejlesztési Perspektíva (ESDP) policentrikus koncepciójával. Nyilvánvaló, hogy a policentrizmus értelmezése az adott államok adottságainak függvényében sok hasonló, s legalább annyi eltérő vonást mutat. Hollandia példája azért lehet érdekes, mert a holland tervezési szakemberek tevékenyen kivették részüket abban, hogy az ESDP megszületett, ugyanakkor a policentrizmusnak a nemzetközi, határon átnyúló értelmezésétől mégis az utóbbi években valamelyest visszaléptek nemzeti keretek közé. A többi ország gyakorlatán keresztül azonban feltétlenül számba vehetők olyan tanulságok, melyek iránymutatásként szolgálhatnak a magyar döntéshozók számára is városhálózatunk kezelése, illetve policentrikusabbá tétele szempontjából. A nemzetállami példák némely esetben válaszként értelmezhetők az EU policentrizmus koncepciójára, melyet az ESPON-kutatások mélyítettek és mélyítenek el, más országok esetében pedig épp a folyamat fordított jellege bizonyítható.

\section{Németország, ahol a policentrikus felfogás mindig is létezett}

Németország területi tervezési rendszere már hosszú ideje a kiegyenlített policentrikus területi fejlődésre orientál, amit maga a föderális államberendezkedés is támogatni igyekszik. A központihely-elmélet vagy a tengelyek fejlesztésének koncepciója csupán két példáját jelentik a policentrikus célok jelenlétének Németországban. A policentrikus koncepció és a központihely-elmélet pedig összekapcsolódik. Ennek kiindulási pontja, hogy a városok nagyságuk és központosultságuk alapján funkciókat töltenek be közelebbi és távolabbi környékük számára, s e központi funkciók kijelölése a területrendezés klasszikus eszközének számít. Az egész országot lefedő módon, egységes kritériumok alapján végezte el a Szövetség közösen a tartományokkal az agglomerációk lehatárolását és a központi-hely szisztéma kifejlesztését. Annak megállapításai a tartományi fejlesztési tervek és programok szerves részét képezik, s aktualizálásuk folyamatosan történik. A területrendezés 
egyébiránt a policentrikus és monocentrikus agglomerációs területek létét is adottnak veszi. Vagyis társadalmi-gazdasági és funkcionális szemszögből a német városhálózat egy szorosan hálósodott policentrikus szerkezetet mutat, mely a városokból és mindenkori vonzáskörzetükből áll, amibe a vidéki térségek gazdasági, szociális és kulturális szempontból többé-kevésbé becsatlakoznak, illetve integrálódnak.

\section{A német városhálózati modell}

A Német Szövetségi Állam és tartományai 1993-ban közös területi tervezési irányelvekben egyesítették szándékukat arra nézve, hogy a regionális és településfejlesztést az ún. decentralizált koncentráció elvére építik. A policentrikus modellre, mint valamennyi területi szint számára releváns modellre tekintenek Németországban (Somlyódyné Pfeil E. 2003).

A településközi együttmüködésen alapuló városhálózatok gyakorlati modellezése Németországban a kilencvenes évek közepén lezajlott. A föderatív államban 1992ben új területrendezési tétel ként határozták meg a városhálózatokat és felvették őket az ún. Területpolitikai Orientációs Keretbe (ORA), aminek köszönhetően első ízben váltak a területrendezési és regionális politika építőköveivé. Az ORA a városhálózatok funkcióit a területi adottságok szerint differenciálta, azonban általánosságban a következő célok elérését rendelte hozzájuk (Adam 1997):

- a túlnépesedett területek tehermentesítése,

- hozzájárulás a strukturális gyengeségben szenvedő vidéki térségek fejlődéséhez,

- az új szövetségi tagállamok felépítésének elősegítése,

- hozzájárulás Németország településhálózatának decentralizált és policentrikus karakterü megerösítéséhez,

- a területrendezésben a fenntartható területi fejlődés céljának szolgálata.

A területpolitikai célok konkretizálása és operacionalizálása érdekében két évvel később az illetékes szövetségi minisztérium kutatási és támogatási irányvonalat nyitott (ExWoSt), amelynek keretei között 11 modell-városhálózat nyomon követésére került sor. A kísérletbe bevont kooperációs modellek összesen 60 város együttmüködését intézményesítették, melyek közül mindösszesen öt volt a központi funkció nélküli község, míg 21 felsőfokú központi, a többi középfokú központ-szerepkört tölt be. Népességszámuk alapján a 80 ezres kategóriától az 1,6 millió lakost számlálóig sokszínüek a hálózatok. Az utóbbi kiugró nagyságrendjét München részvétele indokolja a MAI nevet viselö együttmüködésben. Amennyiben ettől az egyetlen óriásszervezettől eltekintünk, Németországban a városhálózatok átlagosan közelítően háromszázezer före kiterjedően müködtek az 1997-es statisztikai adatok alapján.

A városhálózatok tevékenységének középpontjában a telephely-politikai törekvések állnak, mindenekelött a gazdaságösztönzés, a marketing, a technológiatranszfer, a turizmus, a kultúra és a közlekedési infrastruktúra területein. Az esetek többségében a megfogalmazott cél az önkormányzatok mozgásterének kitágítása és regionális 
léptékü fejlesztési folyamatok generálása. A területi politika számára pedig azért bírnak relevanciával e szervezetek, mert többségükben strukturális válságban lévő közép- és kisvárosokat integráltak. S tagadhatatlan, hogy rajtuk keresztül az agglomerációkon kívül eső térségekben is lehetőség nyílik - a diszperz és véletlenszerü fejlődés helyett - a tervszerüen irányított területi fejlődésre (Mehwald 1997).

Az ORA mint politikai dokumentum négy jövőképet koncípiált, nevezetesen:

- a településstruktúrára és benne a városhálózatokra,

- a környezetre és térhasználatra,

- a közlekedésre,

- továbbá a rendezési tervezésre és a fejlesztésre vonatkozókat.

Németországban tehát az önkormányzatok közötti együttmüködés új területeként látszottak körvonalazódni az ún. városhálózatok. Speciális közös jegyüket az együttmüködés alanyainak nagyságrendje szolgáltatja, hiszen azok túlnyomó többségükben a nagy agglomerációkon kívül esö, strukturális problémákkal küzdö térségek közepes nagyságú, ritkábban kisvárosai. A területpolitika a városhálózatokat a maga számára új, a gyakorlati megvalósításra koncentráló és problémaorientált eszközrendszerként kezeli, melynek müködési feltételét a helyi önkormányzati szintü feltétlen elfogadottság jelenti (Melzer 1997).

Aztán Németországban 2004-ben a Szövetségi Építésügyi és Területrendezési Hivatal (Bundesamt für Bauwesen und Raumordnung) állította fel azokat a szcenáriókat, melyek az ország jövőképére vonatkoznak. A négy forgatókönyv közül (melyek részletes ismertetésétől eltekintünk) a $\mathrm{B}$ variáns „Az intern módon policentrikusan hálózatosodott önálló felelősségü nagyrégiók társadalma és területe" címet viseli. E forgatókönyv a decentralizált koncentráció társadalmi-gazdasági paradigmáját kívánja továbbvinni, melyet először az ORA fogalmazott meg. Ennek tükrében úgy látszik, hogy a korábban kijelölt maximum hét európai jelentőségü német metropolisztérség koncepciója felülvizsgálatra szorul, ugyanis az Unió is megrótta emiatt Németországot. A területet lefedő regionalizáció nézőpontjából politikai konszenzus született arra vonatkozóan, hogy néhány célzott metropoliszrégió területileg diszkriminatív fejlesztése nem szolgálja az ország versenyképességét (Stiens 2004).

Míg az elmúlt időszakban az ún. nagyrégiók kialakítása térgazdaságilag volt támogatott Németországban, addig a policentrikus fejlődést fölvállaló szcenárió értelmében az állam a területfejlesztést többé-kevésbé leadja regionális szintre, illetve az önkormányzati kooperációk szintjére. A decentralizáció lényege ebben az értelemben, hogy az állam a területrendezési és fejlesztéspolitikai eszközöket és tevékenységeket visszafogja szövetségi és tartományi szinten azért, hogy egyrészt csökkentse a központi kiadásokat, másrészt, hogy privát szereplöket és vállalkozásokat vonjon be a maga tehermentesítése érdekében. A régiók önállóságának jelszava alatt azonban e decentralizációs folyamat ismét a területi különbségek növekedéséhez vezethet. 


\section{A központi helyek elméletének adaptációja a keleti tartományokban}

Németországban a központi helyek elméletének alkalmazását értelemszerüen kiterjesztették az új tartományokra is, hiszen annak célja a kiegyensúlyozott életkörülmények biztosítása az állam minden térségében. A demográfiai helyzetben, a társadalomban és a kereskedelemben bekövetkezett strukturális változások ellenére a központi helyek elméletéhez ragaszkodnak a német területi tervezők.

A szakemberek hangsúlyozzák, hogy a központi-hely koncepció semmi esetre sem azonosítható a centralizációval. A használata magyarázható azzal az egyszerü jelenséggel, hogy az irányítási eszközök lehetőségei korlátozottak és a pénzügyi eszközök végesek, ami megkívánja kiválasztott dinamikus centrumokban való fölhasználásukat. Vagyis olyan települési elemek fejlesztését célozza, melyek növekedési dinamikát és önfejlődést mutatnak, s amelyek környezetük irányában impulzusokat tudnak leadni. Ma már a központi helyektöl nem csupán az ellátó funkciót követelik meg, hanem a fejlesztési funkciót is, mint olyan potenciált, mely a központi helyeket és azok környékét erösíti. A keleti tartományokban a központi helyek tekintetében létezik két fejlesztési súlypont, egyrészt az alapfokú centrumokban az infrastrukturális kiépítettség standardjának és a fejlesztési funkciónak a biztosítása és karbantartása, másrészt a felső- és középfokú központok telephelyi vonzerejének növelése magas értéket képviselö letelepülést és ellátást garantáló szolgáltatások útján.

A német területi tervezők szerint a hozzáférhetőség szemszögéből a döntéseknek a központi helyeket kell szem elött tartaniuk, egyfelöl a követhetőség, másfelöl az egységes kritériumokra támaszkodás érdekében. Tehát a szolgáltatások és intézmények meghatározott koncentrációja a központi helyeken és megfelelő elérhetőségük biztosítása jelenti azt a lényegi föltevést, aminek segítségével a vidéki térségek számára is garantálható az ellátás (Bergfeld 2000).

\section{Hollandia és az ESDP változó viszonya}

Hollandia a kezdetektől részt vesz az európai integrációs folyamatban, miközben erről az országról azt tartják, hogy talán a legkifinomultabb a területi tervezési rendszere Európában. Hollandiának nyitott gazdasága van és kedvezményezettje az Északnyugat-Európa természetes kapuja pozíciónak. A holland területi tervezők pedig az elmúlt évtizedben főszerepet játszottak Európa tervezési agendájának vitájában, s a helyi és regionális kormányzatok lelkes résztvevői a határon átnyúló és transznacionális együttmúködések uniós programjainak a területi tervezés területén. Jogosan merül fel a kérdés, miként viszonyul e magatartás a nemzeti területi tervezési politikához? A holland nemzeti tervezés milyen mértékben befolyásolt a nemzetközi szinten bekövetkező változásoktól, illetve az aktuális kérdés az, hogy miért tért vissza az utóbbi időben a hazai tervezési feladatokhoz. Évekkel ezelőtt ugyanis úgy nézett ki, hogy a holland nemzeti tervezési rendszert az európai dimenzió kezdi meghatározni. 
Mielött 2002-ben a parlament megtárgyalhatta volna az 5. policy dokumentumot, a kormánykoalíció megbukott. Jelenleg létezik egy új területi tervezési memorandum, melynek elnevezése Nemzeti Területi Stratégia, amelyet már a jelenleg hatalmon lévő kormány készített elő. E dokumentum alcíme igen beszédes: Tér kialakítása a fejlődés számára. Egyike az új politika legfőbb célkitüzéseinek a városfejlődés korlátozásainak könnyítése, amelyeket még az előző kormány rendelt el a vidék védelmében. Célja a gazdaságnak lökést adni, aminek érdekében a gazdasági növekedés területi akadályait el kell hárítani. Fő iránya ennek a fejlődésnek, hogy a jövőbeli urbanizáció helyének meghatározása az új stratégia tárgya: hol történjenek az építkezések, milyen limitációk fogadhatók el, mely helyeken (Zonneveld 2005).

Az említett kormányváltásig az EU-n belül Hollandia erôs támogatója volt a nemzetek fölötti területi tervezés kialakításának, aminek érdekében erőfeszítéseket tett az Európai Bizottság és más országok meggyőzésére. Tehát az EU-nak bizonyos szerepet kapnia kell a területi fejlődés és governance ügyeiben. Végeredményben a Holland Nemzeti Területi Tervezési Ügynökség erőfeszítései elérték egy európai agenda elfogadását. Egyébiránt a nyolcvanas évektől kezdődően a Területi Tervezési Ügynökség tervezői a nemzeti területi politikát is kifelé tekintve fogalmazták meg, miközben intenzíven kooperáltak a szomszédos országok tervezőivel az európai területfejlesztési politika formálása érdekében. Lényegileg ennek eredményeként született meg 1999-ben az ESDP. Természetesen annak keretei között a holland szakemberek érdeklődése mindenekelőtt az északi-tengeri régió felé fordult, ami Dániával, Németországgal, Franciaországgal, Belgiummal és Nagy-Britanniával való együttmüködést feltételezett.

Érdekes fejleménynek tekinthető, hogy az ESDP megszületése után Hollandiában olyan elképzelések láttak napvilágot, hogy az 5. nemzeti tervezési memorandum térben már kategórikusan nemzetközi legyen, mivel a negyedik memorandum a nemzetközi környezetet még csak illeszkedésében használta, illetve vette figyelembe. Időközben azonban kormányváltás történt, amivel a governance egy új filozófiája került bevezetésre, amely lényegesen kisebb szerepet ad a nemzeti kormánynak és számottevően nagyobbat a provinciáknak és a helyhatóságoknak. A kormány 2004 tavaszán kiadta a területi tervezésről szóló új policy dokumentumát, a Nemzeti Területi Stratégiát. Azonban kiderült, hogy nem csupán a filozófia változott, hanem a politika céljai és tartalma is. A Stratégia bevezetőjében a kormány a továbbiakban nem erőlteti, hogy a provinciák és a helyi önkormányzatok nagyon szigorúak legyenek a területhasználat (zónák) szabályozásában abban az értelemben, hogy hol megengedett lakóházak és új ipari létesítmények építése, minek következtében feloldotta a városok és falvak körüli piros határvonal ideáját. Ez nem azt jelenti, hogy a koncentrált urbanizáció hagyományos célja elavult lenne, viszont a helyi és provinciális kormányzatoknak fokozottan követniük kell a szociális megfontolásokat, illetve több mérlegelési hatalommal fognak rendelkezni a jövőben.

Ily módon megállapítható, hogy meglehetősen nagy szakadék tapasztalható aközött, amit a holland miniszterek és hivatalnokok európai szinten megcéloztak és a hatályos nemzeti területi tervezési agenda között. A jelenleg érvényes Nemzeti Területi 
Stratégiát - a területi tervezési miniszter helyett - négy minisztérium készítette elő, ami a politikai integráció magasabb fokára utal. Összehasonlítva tehát a 4. tervezési memorandummal e stratégia: limitált számú város versenyképessége növelésének hangsúlyozása helyett több figyelmet fordít a régiókra és a városhálózatra, elfogadva a regionalizációnak a városokra és a gazdaságra gyakorolt hatását. A külvilágra vonatkozó vízió, ismét mint a verseny keretfeltétele fogalmazódik meg. Nincs többé utalás közös tervezési agendára a Hollandiával szomszédos államokkal és régiókkal. Vagyis nincs említés az Európai Unióról és annak politikáját meghatározó stratégiáról. Valamennyi térkép befelé tekintő, s a nemzeti területi tervezési agenda európaizálásának értelmében az új stratégia világosan jelzi a visszalépést. Kritikai hangok rámutatnak arra is, hogy amíg a holland területi tervezést egy város-vidék doktrínával lehet jellemezni, s amíg elfogultan az ország zöld szívének (Green Heart) megóvásával van elfoglalva, addig kevés tere lesz a transznacionális európai tervezési ügyekkel való foglalkozásnak (Zonneveld 2005).

Ami a policentrikus koncepció gyakorlati alkalmazását illeti, Hollandiában a policentrizmus számára kiválasztottak és elemeztek egy mintarégiót, amelyben a nemzeti és nemzetközi funkciók különböző városok között föl vannak osztva: Amszterdam (fóváros és politikai, pénzügyi, kulturális centrum), Hága (kormányszékhely) és Rotterdam (a legjelentősebb európai kikötőváros) együttesen alkotják a „Randstad” nevü városrégiót. Globális szempontból London és Párizs után ez a harmadik legjelentősebb metropolisza Európának. Egyébként „Randstad” policentrikus struktúráját a holland kormány támogatásban részesíti, mivel számára létfontosságú, hogy a nemzetközi városversenyben vonzó legyen. Ennek az is az oka, hogy a policentrizmus megvalósítása és igazgatása sokkalta nehezebbnek tünik, mintha monocentrizmusról lenne szó. A szakemberek valószínüsítik, hogy egy létrejött policentrikus struktúra önmagától hosszú távon nem maradna fenn, ahhoz ugyanis ismételten meghatározott intézkedések megtétele szükséges a policentrizmus értelmében (Schindegger-Tatzberger 2002).

\section{Ausztria reflexiói a policentrizmus koncepcióra}

Az osztrák szakemberek álláspontja szerint Ausztria reflexiójának kiindulópontja, hogy az EU-hoz 2004-ben csatlakozott tizek közül a szomszédos országokkal való teljes integrációra lehet fölkészülni a következö évtizedekben, ami a területi viszonyok megitélésétöl és kezelésétöl a határon átnyúló, illetve határ nélküli nézőpontot követeli meg. Ugyanis policentrikus területi fejlődés tekintetében Ausztria adottságaiból kiindulva a térképek világossá teszik, hogy a policentrikus konstelláció kialakítása majdhogynem kizárólag határon átnyúló jelleggel képzelhető el.

Amennyiben nemzeti vagy regionális szinten úgy tekintünk Ausztriára, mint egy a szomszéd államoktól elválasztott szigetre, akkor területi struktúrája inkább monocentrikus karakterü, semmint policentrikus. Mindössze Felsö-Ausztria és Karinthia centrumterülete mutat némi többpólusú jelleget a tartományi székhelyüket illetően. Az egyetlen tételszerüen policentrikus struktúra a vorarlbergi Rajna- 
völgyben fedezhető fel. Az európai államok városodottsági fokára elvégzett összehasonlítás bizonyította Ausztria településstruktúrájának alacsony urbanizáltságát. Vagyis nemzetközi viszonylatban az osztrák városok megoszlási mintája kifejezetten monocentrikusnak nevezhető, amennyiben az országot szigetként fogjuk föl. Ha a városokat területi szempontból és a határok figyelmen kívül hagyása mellett vizsgáljuk, úgy Bécs térségében különösképp fölfedezhetők a policentrikus fejlődés jegyei, ami egy intra-regionális mintamodellt képez le. Hasonló sưrüsödési pontként csak a Klagenfurt-Villach- és a Linz-Wels-Steyr-térség értelmezhető, mint amelyről a policentikus fejlődés nézőpontjából gondolkodni lehet. Ehhez kapcsolódóan az osztrák szakemberek hangsúlyozzák, hogy a fejlődés ebben az esetben a koncepcionálisan megalapozott és stratégiailag érvényesített irányítását jelenti az érintett városfejlödés funkcionális szegmensének, nem pedig a városoknak átengedett önfejlődést a „laissez faire” értelmében (Schindegger-Tatzberger 2002).

Noha Ausztriában a policentrizmus korábban nem képezett vitatémát, mégis voltak osztrák példák a decentralizációs megközelítésre, amelyek akár a policentrikus idea gyakorlatba átültetéseként is fölfoghatók. Ez volt „A keleti régió településpolitikai koncepciója - Koncepció egy decentralizációs stratégiára Bécs környékén", valamint a „Településfejlesztés és a vállalati telephelyek a salzburgi központi térségben" c. szakprogram. A keleti régióban 1993-ban egy decentralizációs stratégiát helyeztek elötérbe, melynek a városkörnyék szuburbanizációjának szcenáriójától kellett a tartományi székhelyváros urbanizációja szcenárióig eljutnia. Bécs vonzáskörzetében tehát a decentralizáció szempontjából szóba jövő fejlődési centrumokat elemzéssel azonosították be. A decentralizált koncentráció koncepcióját alkalmazva a régió ma már figyelemre méltó telephelyi adottságait a tömegközlekedésre építette föl, mely nagyobb mértékủ népességnövekedés és területigény jelentkezése esetén megoldást tud kínálni a szuburbanizáció folytatódásának irányítására.

A Salzburgi tartományi fejlesztési program a decentralizált koncentráció és a településfejlesztés jegyében született meg. Salzburg város környékén bizonyos regionális centrumok célzott támogatását vették tervbe, annak érdekében, hogy azok a még meglévő zöld gyürükről, illetve a peremterületekről a kiköltözési nyomást átvegyék. A Salzburgi központi térségnek a fejlesztési programból merített strukturális modellje további következményekkel jár. A háromszintü modell (a központi helyek A, B és C típusára épít) lényegileg annak az alapelvnek a realizálását jelenti, miszerint a településnövekedést megfelelő fejlesztési pólusokba kell koncentrálni abból a célból, hogy a fennálló központi helyeket a rendelkezésre álló infrastruktúrával - a vonalas helyközi közlekedési tengelyek révén - a tágabb térség fejlődésében különösképpen előnyben részesítsék. Ebben a rendszerben a regionális központok rendelkeznek a legmagasabb színvonalú ellátással és telephelyi javakkal, amelyeket funkciójukban meg kell erősíteni, illetve szolgáltatási kínálatukat ki kell építeni, továbbá a jövőbeli lakásépítési tevékenység súlypontjaiként a lakásszámnövekedést föl kell fogniuk. 
Ausztriában a policentrizmus fogalma alatt funkciómegosztást érvényesítenek a városok között. Az ún. regionális centrumok birtokolják a legmagasabb színvonalú ellátó- és telephely-képességet. A regionális mellékcentrumok azokat a településeket jelentik, melyeket magas szintű ellátási és telephelyi minőség, továbbá kielégítő építési terület és annak bővítési potenciálja jellemez, s ahol a településfejlesztés öndinamikájának messzemenően teret kell engedni. Az ún. kiegészítö települések azok a regionális centrumokkal határos települések, melyek a központtal szerves együttélésre vagy legalább egy ilyesfajta funkcionális szimbiózisra törekszenek. Az utóbbi településeken az adott telephelyi minőségen alapuló önfejlődési dinamika megengedett. Minden további település, tekintettel településszerkezetére, a megnövekedett lakásépítési tevékenység számára kevésbé alkalmas, minek következtében a település fejlesztését a saját igényeikre kell korlátoznia.

A policentrikus koncepció Ausztria esetében nyilvánvalóvá teszi, hogy a következő évtizedben várható integráció megkívánja a területiségnek a határokon átívelő, illetve határ nélküli szemléletét. Vagyis a policentrikus konstelláció Ausztria esetében szinte csakis határokon átívelő módon értelmezhető. A városok megoszlása Ausztriában évtizedeken keresztül stabil volt, s a lakónépesség mobilitása sem idézett elő lényeges változásokat a településhálózat strukturális szerkezetében. Mégis az Osztrák Szövetségi Kancellária számára készített szakértői anyag arra az álláspontra helyezkedik, hogy feltétlenül szükség van a jelenlegi város-, illetve településstruktúrának az európai jövőképre tekintettel való felülvizsgálatára, mivel a Strukturális Alapok új orientációját megalapozó dialógusba csak annak révén lehet bekapcsolódni (Schindegger-Tatzberger 2002).

Végső soron úgy vélik, hogy a policentrizmus jövőképe nem más, mint egy régi idea számára kialakított új szókép. Ennek ellenére a lehetséges fejlődési irányokra vonatkozó forgatókönyveket föltétlenül vita tárgyává szükséges tenni. Egyébként az osztrák városrégiókon belüli, a többközpontú jövőképnek megfelelő fejlesztés nem csupán a települési területek iránti kereslet decentralizált irányítását fogná át, hanem kiindulópontja lenne a magas hierarchiaszintü magán- és közintézmények decentralizációjának. Ennek megvalósítása többirányú együttmüködést föltételezne az érintett városok önkormányzatai és a regionális tervezési hivatalok között, s igényelné az illeszkedő infrastruktúra kiépítését a régiók közlekedési feltárása érdekében. Az elképzelések egyik magyarázata, hogy a szomszédos ország meg van győződve arról, hogy az új területi jövőkép alkalmazásával - jobban, mint eddig -, befolyásolható lenne a vállalatok, a magánháztartások és a hivatalok telephelyi magatartása.

\section{Új technikák a városi vonzáskörzetek kezelésére Franciaországban}

Franciaország történetileg a központosított állammodell szerint fölépített, azonban már az 1960-as években megjelent egyfajta provokálása a policentrizmusnak a „Párizs és a francia sivatag” kifejezéssel. A második fázis, amikor a policentrizmus szerephez jutott, 1982-ben kezdődött, a dencentralizációs reform útjára bocsátásával. A reform révén a városok és régiók nagyobb döntési kompetenciához jutottak. 
Természetesen az EU területi fejlődése és annak jövője további vitákat gerjesztett a policentrizmusról (Schindegger-Tatzberger 2002).

Vita van a policentrizmus értelmezése körül is, hiszen annak fogalma igen tág és különböző szinteken értelmeződik. Ezzel együtt a többközpontúság és a decentralizáció, mint a városkoncentráció egyetlen alternatívája jön szóba, amelynek vonatkozásában a közlekedési hálózat formája kulcsszerepet játszik. A policentrizmus megvalósitásához leginkább a regionális szint mutatkozik alkalmasnak, mivel az ágazati politikák és a horizontális koordináció hozzájárulása ott tehetnek jelentöségre szert.

\section{A területi decentralizáció és az új francia várospolitika kezdete}

Az 1982-ben útjára indított francia decentralizációs reformnak általában a közigazgatás átstrukturálására vonatkozó jellemzői szoktak a szakma érdeklődésének középpontjába kerülni, s kevéssé kap figyelmet a reformnak a francia területi tervezési rendszerre gyakorolt hatása, amivel összefüggésben az állam új hatáskörökkel ruházta fel a területi köztestületeket, különféle tervezési jogosítványokat telepített a régiókhoz és a települési önkormányzatokhoz. A tervezési kompetenciák a decentralizált állami irányítás kulcsfontosságú eszközeivé váltak, melyeken keresztül a decentralizáció hatékonysága - többek között - biztosithatóvá vált (Somlyódyné Pfeil 2005).

A francia decentralizációs reform bevezetése óta a tapasztalatok összegyüjtésére megfelelö idő állt rendelkezésre. A francia törvényhozó az utóbbiak birtokában, 1999-ben arra a megállapításra jutott, hogy a közigazgatás széttöredezettsége már nem felel meg a társadalmi fejlödés támasztotta követelményeknek. Ezért egy újabb reformhullám jegyében három jelentős törvény megalkotására határozta el magát, úgy, mint a települések közösségeiről szóló, a területrendezésre és a területek fenntartható fejlesztésére vonatkozó, valamint a városok szolidaritásáról és megújításáról szóló törvény kibocsátására. Az utóbbi törvény alapjaiban módosítja a várostervezés eszköztárát és a városok tekintetében komplex szemléletet közvetít. A jogalkotót az a fölismerés vezette, hogy a francia települési intézményrendszer fejlödését alapjaiban meghatározza a települések közötti együttmüködés dinamizmusa, tehát elkerülhetetlen az állam és az önkormányzatok kapcsolatrendszerének újrafogalmazása (Dubois-Maury 2001). A városok szolidaritásáról szóló törvény globális szemléletet követel meg a városoktól, mivel tervezési és fejlesztési szempontból a várost egységben kezeli vonzáskörzete egészével, sőt elvárja tőle a fenntartható fejlődés elvének érvényesítését.

Abból a helyzetből kiindulva, hogy az ezredfordulón a tizenötök Európai Uniójában Franciaország rendelkezett a helyi önkormányzatok több mint felével, miközben a városok és városi térségek gyors átalakulási folyamaton mentek keresztül, a Parlament kibocsátotta a települések közötti együttmüködést erösitö és egyszerüsítö törvényt. Ennek alapelve a városi és vidéki térségek egészének összehangolt fejlesztése, mely egy új várospolitika kezdő hangjait adta meg. Az interkommunális kooperációnak noha nagy hagyományai voltak addig is, e törvény vállalta fel a mintegy húsz év alatt kialakult együttmüködési struktúrák felülvizsgálatát és egyszerüsítését. 
Ennek lényege, hogy a településhálózat demográfiai és területi sajátosságaira alapozva a települések földrajzilag összefüggö és koherens halmazaiból ún. közösségeket intézményesitett, melyeknek három típusa különböztethetö meg:

- a nagyvárost övezö települések közössége - olyan összefüggő, urbanizált településegyüttes, amelynek legalább félmillió lakosa van;

- az agglomerálódott települések közössége - összefüggő, úgyszintén urbanizált településegyüttes, amely legalább ötvenezer lakossal rendelkezik és egy vagy több tizenötezer föt meghaladó népességszámú település körül helyezkedik el;

- a kis- és közepes méretü települések városi közössége - összefüggö folyamatos beépítettségü urbanizált övezet, amelyhez legkevesebb 3500 és legfeljebb ötvenezer fős lakosság tartozik.

Franciaországban a jövő várospolitikájának központi fogalma a koherencia, ami magában foglalja egyfelől az összehangolt térségfejlesztési koncepció és a különböző ágazati fejlesztési dokumentumok (közlekedés-, kereskedelem- és lakásfejlesztés) kötelezően megteremtendő kapcsolatát és kompatibilitását, továbbá a településközi szint kiemelt kezelését, ami a korábbi évtizedek során már kiformálódott horizontális együttműködésekre épít. Például a települési lakásépítési terv kidolgozása az önkormányzatok közötti együttmüködési közösségek feladata, aminek célja a szociális sokszínüség megteremtése a városrégió szintjén. A terv megvalósítására is felhatalmazásuk van a városoknak, amely célból létrehozhatnak városfejlesztési vegyes tulajdonú társaságokat vagy akár városrendezési és építési közhivatalokat is.

A francia állam saját intézményrendszere megerősítéseképpen önálló Városügyi Minisztériumot alapított, mely fontos szerephez jutott a 2000 és 2006 közötti időszakra meghirdetett várospolitika végrehajtásában. E várospolitikának igen figyelemre méltóak az alapelvei, melyek egy differenciált és koncentrált, megvalósításorientált politikára utalnak. Ráadásul törekszik a döntési folyamatok demokratizálására is (Écrement 2001).

Az újabb reformokig vezetö folyamat hátterében látni kell a meglehetösen sokszereplös és sokszintü igazgatási rendszer egyszerüsitésének, valamint a városi terek fejlödése kézbentartásának határozott szándékát. E várospolitika a hozzákapcsolódó tervezési és finanszírozási rendszerrel válik teljessé, amikor a Városügyi Minisztérium a városokkal kötött állami szerződések keretei között az ágazati minisztériumok beruházásait is koordinálja a települési közösségekben felállított tervek megvalósítása céljából. Mint arra fentebb rámutatni igyekeztünk, az együttmüködés-tervezésprogramozás-finanszírozás eszközrendszer gyökerei már az 1982-es decentralizációs reform során egyértelműen megjelentek, melyek mára egységes várospolitikává kovácsolódtak össze Franciaországban.

\section{A hosszú távú területi fejlódés francia szemléleti alapjai}

Az ezredforduló után a jövőkutatás egyik termékeként állt elő az a négy forgatókönyv, amely Franciaország hoss zú távú területi tervét jelenti 2020-ig elöretekintve. A francia kormány adott megbízást a DATAR (Területrendezési és Regionális 
Fejlesztési Delegáció) számára, hogy készítse el a szcenáriókat a kívánatos jövőről. Lényegében a DATAR feladata nem a területi terezési folyamat helyettesítésére vonatkozott, hanem annak figyelemmel kísérésére és viták gerjesztésére, annak érdekében, hogy a tervezés és fejlesztés sarokköveit, a célirányos kezelési módokat dolgozza ki a politika számára. A négy forgatókönyv két ellentétpárra épül, melyek egyidejüleg hatnak, és a lehetőségek fesztávját beszükítik: egyfelől a globálislokális között létező feszültségről van szó, másfelől arról az ellentétről, mely a hagyományos jakobinus és girondista felfogás szervezeti és politikai reagálása között feszül. Az első dichotómia a gazdaság jelen helyzetét képezi le, míg a második a francia forradalom gyökeréig hatol. A jakobinus-girondista páros lényegében a lokális-globális ellentétpárra adott politikai válasz, mely messzemenően meghatározza a területi tervezés és a kapcsolódó intézmények képét. A neojakobinus vízió a 3. szcenárióban, mint a „megújított centralizmus” jelenik meg, melyet egy szigorú központi állam által megszabott hierarchia jellemez, egyúttal lekapcsolódást és visszahúzódás testesít meg a nemzeti területre. Ezzel szemben a neogirondista jövőkép a 4. forgatókönyvben a „hálózatos policentrizmusként” kerül előterjesztésre, mely a térnek és az intézményeknek hálózatos koncepcióját föltételezi, ami Európa felé való nyitással és a politikai akaratok újrastrukturálásával párosul. A forgatókönyveket tehát e kettős paradoxon határozza meg, melyek közül a jakobinusgirondista ellentét választási lehetőséget biztosít és kötelezettségvállaláson alapszik, míg a globális-lokális páros átalakítja a társadalmi szerkezeteket.

A négy fölvázolt forgatókönyv közül a DATAR a policentrikus Franciaország fölépítését tartja kívánatosnak egy policentrikus Európában. Ennek indoka, hogy e forgatókönyv tudná leginkább szolgálni és egymással összekapcsolni a fönntartható fejlődés három követelményét: a szolidaritást és a társadalmi kohéziót, a gazdasági versenyképességet, valamint a környezeti egyensúlyt. A policentrikus koncepció a hatékony területi dinamikára épül, következésképpen helyi és nemzeti szinten egyaránt változásokat fog eredményezni, ami a területi tervezéstől a feladatok növekvő komplexitását kívánja meg. E forgatókönyv természetszerűen reagál az EU-nak a policenrikus Európára vonatkozó elképzelésére, amely az ESDP-ben fogalmazódott meg. S végső soron a franciák számára visszacsatolást jelent, azokhoz a reformokhoz, amik életre hívták a ,pay”-ek intézményében és az agglomerációkban megtestesülő önkormányzati együttműködéseket, melyeket a polgári társadalom megújításaként fognak föl, minthogy az állampolgároknak is mind szélesebb körü részvételt biztosítanak. Egy állami reform megkerülhetetlen, annak érdekében, hogy a globalizációt befolyásolni lehessen - vélik a franciák. Ugyanis a szolgáltatások területén bekövetkezett nyitás és a globalizáció együttesen megkérdőjelezik a helyi szintű közszolgáltatási területek funkcióját. A közszféra modernizációja megköveteli, hogy a civil társadalmat bevonják a fejlesztési projektek kidolgozásába és megvalósításába (Guigou-Peyrony 2004).

A területi kohézió követelménye lényegi célját adja a területfejlesztési politikának és területi tervezésnek, s a franciák úgy tekintenek a régióra, mint amely területi egység szolgáltatni tudja a különféle strukturális szintek közötti hálózatok létrejöttét 
és a szolidaritást. Végső soron egy, a centrum-periféria modellel ellentétes új elvet támogat a modernizáció: a kis- és közepes méretű városoknak - melyek a francia településhálózatot legföképpen jellemzik - vezető szerepet szánnak ebben a keretben. Az új közpolitikáknak pedig feladatuk lesz, hogy figyelembe vegyék a városok különböző profilját és specializációját, amikor beavatkozási területeket és pólusokat határoznak meg, melyekböl a fönnmaradó területeket ki kell szolgálni.

A nagytérségi átstrukturálódás egyik szembetűnő jegye, hogy a francia regionális metropoliszok és középvárosok együttműködnek és interregionális városhálózatokat alkotnak, s ezeknek a régióközi egységeknek a fejlődési dinamikája egyértelmüen tapintható. E fejlödési irány már a központi közigazgatás müködésére is kihatott, ugyanis a DATAR által 1998-ban lefolytatott felmérés azt mutatta, hogy 88 vizs gált igazgatási egység közül 33 szerv tevékenységét már régióközi funkciómegosztásban szervezte meg. Így a DATAR elhatározta, hogy létrehoz egy interregionális szervezetrendszert, mely hat egységet tartalmazna, s valamennyi alapstruktúráját egy-egy városhálózat képezné.

Lényegüket tekintve policentrikus városhálózatokról van szó, hat nagy településhálózati egységről, mivel a DATAR álláspontja szerint Franciaországnak a pólusait növelnie kell, és sokoldalúbbá kell tennie őket, annak érdekében, hogy a globális gazdaság kapuiként szolgálhassanak. Tehát, amikor interregionális érdekekről és kontextusról gondolkodnak a franciák, akkor e cél elérése a nagy településegyütteseken keresztül történik: a stratégia kialakításánál nem tesznek különbséget városi, vidéki és természeti területek között. A rendszer kizárólag e településegyütteseket erősíti.

Ezen adottságok következtében a policentrikusság forgatókönyvbeli célját a közpolitikák nyilvánvalóan megfelelő variációk menték tudják majd megvalósítani. Vagyis elvek érvényesítéséről és nem egy egységes fejlődési modell keresztülviteléről van szó, ami megengedi a pólusok nagyságrendbeli, sürüségbeli és funkcionális heterogenitását (Guigou-Peyrony 2004).

\section{Összegzés helyett}

Mind gyakrabban hangzik el a kelet-közép-európai térség európai uniós tagállamairól, hogy nem rendelkeznek sem nemzeti várospolitikával, sem pedig az urbánus tereket integráló politikával. Holott a városi terek valójában nem konfliktust vagy akadályokat jelentenek, hanem épp ellenkezőleg, lehetőségeket és hidakat nyitnak meg a fejlődés számára. Kétségtelen azonban, hogy a városfejlődés dimenziói kitágultak, s egyre kevésbé a nemzeti városhierarchiában kell elhelyeznünk a városokat, de mindinkább egy kitágult gazdasági térben, és legalább európai kontextusban mérendö helyük és szerepük. Minthogy a városok még mindig kritikus helyei az identitásnak, a cselekvésnek és döntéshozásnak, s hasonlóképpen döntő fontossá gúak a nemzeti gazdaságok számára (Parkinson 2005).

Töredelmesen be kell vallani, hogy a fölsorakoztatott államok városfejlesztési politikájából, a többközpontú fejlesztés koncepciójával való kapcsolatából csak szilánkokat volt lehetséges felvillantani. Ez pedig legfeljebb arra alkalmas, hogy 
ráirányítsa a hazai politikaformálók figyelmét a városhálózatokra, a városi vonzáskörzeti együttmüködések intézményesítésének kérdéseire, esetleg egy új városfejlesztési stratégia megfogalmazásának sürgető igényére. A bemutatott várospolitikák egyik lényeges közös vonásaként tapintható ki az, ami Franciaországban a differenciált és koncentrációt kifejező politikában, Németországban és Ausztriában az ún. decentralizált koncentrációban összegzödik, de Hollandiában is a decentralizáció felé mutat.

Nyilvánvalóan minden nemzet a maga számára másként értelmezi az elvet, de annak alkalmazása kétségtelen összefüggést mutat az egyenértékủ életkörülmények kiépítésével, az ellátó és szolgáltató intézmények elérhetőségének biztosításával a lakosság számára. A decentralizált koncentráció orientálja a városi, illetve nagyvárosi terek fejlődését. Jelentheti az agglomerációk tehermentesítését a túlzott gazdasági és népességkoncentráció terhei alól, egy decentralizált terület- és településstruktúra kialakításán keresztül $(A R L$ 1999, 166). De jelenti a kisebb városoknak, mint fejlesztési és tervezési egységeknek vonzáskörzetükkel egységben történő kezelését, amikor a fejlődésért viselt felelősség áthelyeződik a kistelepülésekről az önkormányzatok közösségeire, vagyis vonzáskörzeti szintre (Dubois-Maury 2001). Tanulságos, hogy Franciaországban a policentrikus fölfogás kifejezetten szerepet játszott a központosított állam leépítésében, $\mathrm{s}$ a decentralizáció politikája abban is megnyilvánult, hogy a régiók és városok kompetenciáját kiszélesítették, ami a decentralizált koncentráció egy másik megközelítését nyújtotta. A formálódó magyar várospolitika számára pedig mind a koncentráció, mind pedig a decentralizált és differenciált kezelésmód figyelemre méltó szemléleti bázist közvetít.

\section{Jegyzet}

${ }^{1}$ A tanulmány átdolgozott és kiegészített változata a „A policentrikus városfejlesztés megalapozása Magyarországon" c. kutatás számára készült szerzői elemzésnek. Megbízó: Országos Területfejlesztési Hivatal. MTA RKK Dunántúli Tudományos Intézet, Pécs. 2006. Témavezető: Faragó László.

\section{Irodalom}

2006/702/EC Council Decision of 6 October 2006 on Community strategic guidlines on cohesion. Official Journal of the European Union 2006. 10. 21.

Adam, B. (1997) Städtenätze - ein Forschungsgegenstand und seine praktische Bedeutung. Informationen zur Raumentwicklung. 7. 1-5. o.

Akademie für Raumforschung und Landesplanung (1999) Grundriß der Landes- und Regionalplanung. Hannover, Verlag der ARL.

Bergfeld, A. (2000) Ausweiß von Vorranggebieten für Industrieansiedlungen. Raumforschung und Raumordnung 5. 139-149. o.

Dammers, E. (2004) „Szene” - ein Quartett raumordnerischer Szenarien für die Niederlande. Informationen zur Raumentwicklung 1-2. 21-34. o.

Dubo is-Maury, J. (2001) A francia területpolitika aspektusai. Falu Város Régió. Város, lakás, közlekedés Franciaországi tapasztalatok. Különszám. 49-61. o.

Écrement, B. (2001) A kiegészítő eszközrendszer és a partnerkapcsolatok formái. Falu Város Régió. Város, lakás, közlekedés - Franciaországi tapasztalatok. Különszám. 63-83. o.

Guigou, J-L.-Peyrony, J. (2004) Den Raum Frankreichs für 2020 planen. Vier Szenarien und ein Modell einer ,"wünschenswerten Zukunft”. Raumforschung und Raumordnung. 1-2. 1-20. o. Raumentwicklungszenarien aus Nachbarstaaten. 
Halender, E. (2006) Cohesion Policy and cities: preparing urban actions in future Struktural Funds programmes. Directorate General Regional Policy $=$ www.gencat.net/regionsandcities/descarrage/ PLENARY_SESSION\%20II/Elisabeth-Halender.pdf. (2006. december).

Küpper, U. I.-Röllinghoff, S. (2005) Clustermanagement - Anforderungen an Städte und regionale Netzwerke. Deutsche Zeitschrift für Kommunalwissenschaften 1. 60-93. o.

Mehwald, L. (1997) Städtenetze - vom Raumordnungspolitischen Orientierungsrahmen zur Umsetzung. Informationen zur Raumentwicklung. 7. 473-479. o.

Melzer, M. (1997) Schlüsselfragen einer zukunftsfähigen Standortpolitik mit Städtenetzen. Informationen zur Raumentwicklung. 7. 495-508. o.

Niessler, R. (2006) The urban dimension in European Cohesion Policy 2000-2006. Directorate General Regional Policy Head of Unit Spain = www-deutscher-verband-org/seiten/urban- netzwerk/downloads/ 2006-03-30_Niessler.pdf. (2006. december).

Parkinson, M. (2005) Local Strategies in a Global Economy: Lessons from Competitive Cities. Local Development and Governance in Central, East and South-East Europe. OECD LEED Centre for Local Development, Trento (International Conference, 6-8. June 2005).

Schindegger, F.-Tatzberger, G. (2002) Polyzentrismus ein europäisches Leitbild für die räumliche Entwicklung. Österreichisches Intstitut für Raumplanung, Wien. Megbízó: Bundeskanleramt, Abt. IV/4.

Somlyódyné Pfeil E. (2003) Önkormányzati integráció és helyi közigazgatás. Dialóg Campus Kiadó, Studia Regionum. Budapest-Pécs.

Somlyódyné P feil E. (2005) A városok az átalakuló közigazgatási rendszerekben és a területi politikában (Nemzetközi kitekintés). Magyar Közigazgatás. 4. 193-203. o.

Somlyódyné Pfeil E. (témavezető) (2006) A pólus-programok irányításának, menedzselésének szervezeti össze függései. Kutatási Zárótanulmány. Megbízó: Nemzeti Fejlesztési Ügynökség. MTA RKK Dunántúli Tudományos Intézet, Pécs.

Stiens, G. (2004) Aktuelle deutsche Raumentwicklungszenarien im Vergleich mit Szenarien aus benachbarten Staaten. Informationen zur Raumentwicklung 1-2. 77-106. o.

Strubelt, W.-Gatzweiler, H-P.-Kaltenbrunner, R. (szerk.) (2000) Raumordnungsbericht 2000. Band 7. Bundesamt für Bauwesen und Raumordnung, Bonn.

Zonnoveld, W. (2005) The Europeanization of Dutch National Spatial Planning: an Uphill Battle. DISP 4. 4-15. o.

\section{CONCEPTION OF EU POLICENTRISM AND STATE CITY POLICIES}

\section{EDIT SOMLYÓDYNÉ PFEIL}

In the national urban policies and the institutionalisation of the co-operation of urban areas and urban networks there has been a paradigm shift in the member states of the European Union. The framework for this is provided by the structural policy of the EU, as the spatial disequilibrium of the location of the cities is a factor setting back the strengthening of spatial cohesion. The changes in the urban policy highlighted in the article are related to the modernisation and the improvement of their efficiency of the administrative structure in the member states, on the one hand, and the constraint of economic development and the strengthening of the competitiveness of the cities, on the other hand. The main message of the analysis is that the suitable level for the implementation of the polycentric concept is the regional tier, both within the nation states and at an international level. The concept can be fully realised if the administrative principle of decentralisation is mixed with the principle of spatial concentration. Considering that Hungary has not defined an urban development strategy since the systemic change, in fact, there has not been a real urban policy in Hungary since then, the practice of other countries can serve as guidelines for the Hungarian decisionmakers for the planning and the development of the urban network, and for making the network more polycentric. 